\title{
The Novel as Textbook
}

\section{Elisabeth Gareis, Martine Allard, and Jackie Saindon}

The use of authentic literature, especially novels, has proven electrifying for teachers as well as students: a development mirrored in the success of related methodologies and the increasing availability of materials accompanying literature. The benefits of using novels as textbooks are numerous. Research consistently shows the benefits of extended reading; novels are motivating and authentic; and they can support any curriculum and be used in a variety of programs. Issues discussed in the article include a rationale for using novels as textbooks, selection criteria, ways of teaching discrete and integrated skills, and reflections on the pros and cons of using literature to teach English.

Le recours à la littérature authentique, notamment les romans, s'est avéré électrisant tant pour les enseignants que les élèves: ce phénomène est reflété dans les résultats positifs découlant de méthodologies connexes et la disponibilité croissante de matière pédagogique qui accompagne la littérature. Les avantages d'employer les romans comme manuels sont nombreux: la recherche fait ressortir, de façon continue et constante, les bienfaits de la lecture; les romans sont stimulants et authentiques; et ils peuvent appuyer n'importe quel programme d'études. L'article développe plusieurs thèmes, dont le fondement de l'emploi des romans comme manuels, des critères de sélection, des stratégies pour enseigner des habiletés discrètes et intégrées, et des réflexions portant sur le pour et contre d'employer la littérature pour enseigner l'anglais.

\section{Introduction}

ESOL textbooks are invaluable resources for teaching English, but they are not the only choice for a given course, program, or curriculum. As ESOL theory supports the use of literature in the classroom (Gajdusek, 1988), we propose that novels can supplement textbooks or form the central focus of instruction.

Novels allow for extensive reading (i.e., the reading of a large quantity of text), which has been shown to facilitate general proficiency (Day \& Bramford, 1998; Grabe, 1991) and build fluency (MacGowan-Gilhooly, 1991) as well as vocabulary (Horst, 2005; Krashen, 1989). Novels also increase motivation by providing narrative and plot (Elley, 1991; Cho \& Krashen, 1994; Rodrigo, 1995), a fact evidenced by the growing number of educational novels or narrative-style textbooks in such areas as physics, math, history, and economics (Schneider, 2001). 
Furthermore, literature, with its compelling plot, characters, and often rich cultural content, lends itself to the integration of reading education with the development of other language skills including writing and cultural awareness, as well as listening (e.g., books on tape) and speaking (e.g., role-plays and discussions, Lazar, 1993). In addition, novels can be changed easily to fit current events or students' interest and may be less expensive than most textbooks.

Literature also provides contact with the English language at its most expressive and enhances students' sense of style (Vandrick, 1997). As Povey (1979) wrote, "Literature gives evidence of the widest variety of syntax, the richest variations of vocabulary discrimination. It provides examples of the language employed at its most effective, subtle, and suggestive" (p. 162).

Unabridged novels are especially effective. They not only provide authentic exposure to the English language, but also offer the quantity of reading required to produce substantial improvement in reading skills. Students can be immersed in a context and activities for more than one or two days and thus practice all language skills systematically (Gajdusek, 1988; Gareis, Allard, Gill, \& Saindon, 1997, 1998, 2000; Gareis, Allard, \& Saindon, 1998). An added benefit is that many novels have been adapted for film and in conjunction with their visual counterpart, can be used to teach other literacy skills such as film literacy (Pally, 1997; Seger, 1992).

\section{Choosing a Novel and Creating a Timeline}

Novels can be used for a variety of programs and proficiency levels in secondary, higher, and adult education. Our own experience has been mostly with intermediate and advanced postsecondary students in an intensive English program. Which novels are appropriate depends on the students' proficiency level, age, and interests, as well as course objectives and suitability of content. Literary as well as cinematographic value (of any existing film adaptations) can also be considered.

Applying Krashen's (1989) i+1 input hypothesis and Nation's (2001) recommendation that unfamiliar vocabulary in extensive reading materials should not exceed $2 \%$, the target is texts of which the degree of difficulty is slightly above that of the students' current level. One general rule that we have followed successfully is that if a page has more than five or six new words that are essential for comprehension, the reading may be too difficult. In other words, a book has to be below the frustration level and within the $i+1$ parameters of the student audience if the class is to enjoy it and gain from the experience.

To determine the degree of difficulty of a novel and the suitability of its content, prereading is crucial. Even so, it may not be possible to avoid occasional problematic content such as offensive language or sexual innuendo. Hot topics can be approached by giving students a chance to skip the 
potentially unsettling material, by acknowledging such passages but not focusing on them, or by dealing with the material openly and creating teachable moments around it (e.g., by translating slang into more formal registers, Gareis, 1997).

A list follows of some suggested novels for intermediate and advanced proficiency levels, most coming with film adaptations. The list is far from comprehensive and is intended only as an example of novels that can be used successfully in ESOL classes.

\section{Intermediate}

Cisneros: The House on Mango Street

Flagg: Fried Green Tomatoes

Kosinski: Being There

Kroeber: Ishi, Last of his Tribe

Lee: To Kill a Mockingbird

Orwell: Animal Farm

Twain: The Adventures of Huckleberry Finn

\section{Advanced}

Fitzgerald: The Great Gatsby

Grisham: The Firm

Kesey: One Flew Over the Cuckoo's Nest

King: Rita Hayworth and the Shawshank Redemption

Kinsella: Shoeless Joe

Tan: The Joy Luck Club

Walker: The Color Purple

After a selection has been made, teachers need to decide how much reading is reasonable per day or week in their specific ESOL context. Our experience with intermediate students is that they tend to be comfortable reading 10-15 pages per day.

For example, to cover a relatively short novel such as Kosinski's Being there (1971), we assigned passages daily and were able to cover the novel in two weeks. If out-of-class assignments such as writing reflective essays, keeping a journal, or conducting research are added, extra time between readings can be allowed. Longer novels or those assigned weekly can provide sufficient material for several weeks or a full term.

\section{Using Novels to Teach Discrete Language Skills \\ Reading Skills}

For students used to fixed-length, intensive reading passages in traditional ESOL textbooks, extensive reading can at first seem daunting. However, even after only a few sessions of reading a novel, our students frequently 
comment that reading has become far more enjoyable and that extensive reading has helped them diversify their reading habits. Another effect we have noticed is that students' intrinsic interest in narrative and plot makes it easier to cover the skills usually taught in reading class including prediction, identification of main ideas and supporting details, skimming, scanning, and inferring.

Example. Based on a true story, the novel Ishi, Last of His Tribe (Kroeber, 1973) features Ishi as the last member of the Yahi people to survive the conflicts between White settlers and Native Americans. After Ishi arrives in a town in California, he encounters several technological inventions unfamiliar to him. Ishi's perception of the modern world can be used to practice the skill of inferring, with a focus not only on the nature of unknown objects, but also on Ishi's feelings and on the character of the people Ishi meets. This is a quote from the beginning of chapter 4 of the book: "The house shook and settled; the Monster slowed and stopped. Ishi could hear its deep, panting breath. After some moments, its breathing became heavier and it moved away, going out of sound" (pp. 159-160).

This passage, written from Ishi's perspective, invites the reader to infer the nature of the unfamiliar objects Ishi encountered (such as locomotives), as well as how strange the modern world must have appeared to Ishi and how isolated and fearful he must have felt in his new surroundings. With novels often leaving characters' feelings and motivations to readers' interpretation, practicing such skills as inferring becomes a natural and integral part of reading rather than an added separate task.

\section{Vocabulary Development}

Authentic literature is ideal for vocabulary development through in-depth exploration of the often poetic and poignant vocabulary found in quality literature on one hand and through guessing vocabulary from context on the other (Knight, 1994). Guessing vocabulary from context is a critical skill for students preparing for academic studies; most postsecondary courses require large amounts of reading along with strategies to process text effectively (Carrell \& Carson, 1997).

It is, therefore, useful to begin extensive reading instruction with activities that ask students to decide which words to look up and which words to guess. Questions that help students guess vocabulary from context include the following. Is the unfamiliar word a noun, a verb, an adjective, or some other part of speech? Do surrounding words or the larger context provide clues for the meaning? Do you know the prefixes, stem, or suffixes of the word? Can you think of related words? Is there a word in your language that looks or sounds similar?

Example. One sentence on the first page of Ishi, Last of His Tribe (Kroeber, 1973) reads, "Ishi did not take the long, meandering trail which led out of the 
canyon; he crawled on all fours under the wet bushes, then climbed a vertical wall of rock which was a shortcut to the top" (p. 1). One word with which intermediate students may not be familiar and that can be guessed from the context is meandering. Because meandering must be something that a long trail can do, and because the path that Ishi took was a short cut to the regular trail, one can infer that a meandering trail must be curved, not straight.

Once students have practiced guessing vocabulary, they may wish to use the following guidelines for reading extensively (Hunt \& Beglar, 2005; Knight, 1994).

- Read the section once to get the main idea. Try to guess unfamiliar vocabulary.

- Read the section a second time and note any vocabulary that is essential to understanding the story. Look up the vocabulary in a dictionary.

Beyond guessing vocabulary from context, vocabulary development exercises prevalent in intermediate to advanced textbooks can be applied to authentic literature. One can use the vocabulary at hand to analyze word families; study prefixes, roots, and suffixes; explore idioms, collocations, and registers; and expand one's lexical repertoire through synonyms, antonyms, and paraphrases.

Example. The theme of chapter 7 of Animal Farm (Orwell, 1951) is rebellion. To build vocabulary around this theme, students can conduct a treasure hunt for words related to rebellion. Vocabulary items they collect from the chapter may include triumph, surrender, capitulated, in league with, comrades, plotting an attack, secret agent, to give the signal, heroic leader, traitor, true spirit, medals, collaborated, ringleaders, devoted followers, to assemble, carry out the orders, protest, hoisting of the flag.

Students can then arrange the vocabulary into clusters (e.g., positive vs. negative connotations) or along a scale (e.g., most to least peaceful). As the theme of rebellion is embedded in the novel's larger question of societal organization, students can expand on their clusters as they progress in their reading. Eventually, students can use their new vocabulary to discuss or write about conditions that lead to rebellions and various ways to effect political change.

Authentic literature also offers excellent opportunities for individualized vocabulary development. For example, students can keep a vocabulary journal and meet in small groups to share their words and meanings or use this new vocabulary in games such as charades and memory (with new words and their synonyms). With words connected to memorable plots and characters, students often find vocabulary development through reading novels more effortless than through working with textbooks or other texts. 


\section{Listening Skills}

Listening activities common in the ESOL classroom include predicting content, listening for the main idea, listening for specific information, transferring heard information to a chart, and summarizing or retelling passages. Works of literature provide ample opportunities for aural comprehension practice through books on tape, through film adaptations, or through the reading aloud of passages by teachers, guest speakers, or students.

Example. In One Flew Over the Cuckoo's Nest (Kesey, 1962), Nurse Ratched forbids psychiatric patients to watch a game on TV. McMurphy defies the rule by sitting in front of the blank TV acting as if he is watching the game. The fellow patients all join in. The following listening exercise contains Nurse Ratched's reaction.

Before listening to the passage, students try to predict what Nurse Ratched will do. Then they listen to the passage for the main idea (e.g., Is Nurse Ratched going to move McMurphy to a different ward? Is she going to punish him?). Finally, students listen to the passage for specific information or individual words, as in the following cloze exercise in which every word carrying sentence/thought-group stress has been removed (based on Kesey, 1962).

For the first time she takes a sip of___; the cup comes away from her mouth with that red-orange on it. I stare at the rim of the cup in of myself; she couldn't be wearing that color. That color on the rim of the cup must be from , touch of her lips set it "I'll admit that my thought when I began to recognize Mr. McMurphy for the disturbing that he is was that he should most definitely be sent up to But I believe it is too late. Would removing him the harm that he has done on our ward? I

believe it would, not after afternoon. I believe if he were sent to

Disturbed it would be exactly what the patients would would be a to them. They would never be given the that this man is not an-as you put it, Mr. Gideon-" , to see

Answer key: coffee, color, spite, lipstick, heat, smoldering, first, force, Disturbed, now, undo, don't, this, now, expect, martyr, opportunity, extraordinary.

A note on creating exercises. Preparing cloze and other exercises does not have to translate into extra work for the teacher. Students or groups of students can take turns in creating them (e.g., deleting every 10th word, all verbs, all words containing specific sounds, etc.). This allows students to be creative and to hone their English skills.

Speaking Skills

Speaking activities in ESOL classrooms include pronunciation practice, functions and notions, discussions, and presentations. Teachers equipped with a 
curriculum for their course can use novels to teach all speaking skills and can do so in the highly contextualized environment that novels offer.

For example, listening activities can lead to a speaking lesson on intonation and rhythm. Functions and notions (e.g., making requests, negotiating a contract) can be covered by role-playing related scenes from the novel; questions and issues raised by the novel can be discussed in small groups; and students can give presentations on topics such as the author's background, cultural content, or historical context.

A popular assignment is for students to interview native speakers about topics related to the novel at hand and discuss their findings in class. During the interview segment, students can practice functions such as making appointments, making small talk (to warm up the interviewee), paraphrasing questions, and expressing gratitude. During the discussion segment, students can take turns facilitating the discussion, encouraging equal participation, making sure the discussion stays on track, and summarizing contributions at the end.

Example. The following questions pertain to the beginning of The Color Purple (Walker, 1982). Each student can choose one topic for his or her interview project.

- The story takes place in the South of the US in the early 20th century. How was life then for White versus Black people? What has changed since then? What is still the same?

- On p. 9 of the novel, Celie's father tells Mr. that she would come with her own linen and a cow, if Mr. would marry her. What are the dowry and wedding customs in the United States of today?

- Celie remembers that she studied about Columbus in school, but she doesn't remember the details. What is taught in US schools about Columbus? How did he treat the native inhabitants on the islands he visited? Should Columbus be considered a hero or invader?

Quality literature explores themes of importance and social effect. Therefore, it lends itself perfectly to research activities such as interviewing or surveying and to in-class discussion and debate.

\section{Writing Skills}

Writing objectives common in ESOL classrooms focus on topic sentences, supporting details, sentence structure, fluency and accuracy, organization, and exploration of the rhetorical modes of discourse including the narrative, descriptive, expository, or persuasive modes. Novels are ideal for practicing most ESOL writing objectives including introducing the writer to the critical issues of purpose and audience that are fundamental to effective writing.

Rita Hayworth and the Shawshank redemption (King, 1982) is a novella about two men in prison. It details the hardship they endure and the friendship they form. Students can use the text as a springboard for playing the role of 
penpal and writing a letter to one of the novel's characters, with classmates writing back. Students can also write research papers about institutional punishment or practice creative writing by inventing an alternative ending to the story or composing found poems using random words from the novel. To practice sentence mechanics, students can find examples of conjunctions, transition words, or subject/verb agreement, or can test each other on specific grammar points critical to good writing by blanking out all instances of the point in question from a page or chapter.

Example. The following passage adapted from Rita Hayworth and the Shawshank Redemption (King, 1982), has had all punctuation and capitalization removed. Students fill these in and then compare with the original and discuss the differences.

it was on a sunday that andy first came to me i had just finished talking to elmore armitage a fellow who often came in handy to me about a radio when andy walked up $i$ knew who he was of course he had a reputation for being a snob and a cold fish people were saying he was marked for trouble already one of the people saying so was bogs diamond a bad man to have on your case

The passage as it appears in the book:

It was on a Sunday that Andy first came to me. I had just finished talking to Elmore Armitage, a fellow who often came in handy to me, about a radio when Andy walked up. I knew who he was, of course; he had a reputation for being a snob and a cold fish. People were saying he was marked for trouble already. One of the people saying so was Bogs Diamond, a bad man to have on your case. (p. 27)

\section{Grammar Skills}

Although grammar is often taught as a discrete skill, in communicative, integrated curricula it is usually taught in the context of speaking or writing. Novels support the teaching of grammar in both discrete and integrated curricula, with the benefit of having an authentic built-in context and continual recycling of forms and structures. Grammar activities include finding specific examples on a page or series of pages, creating cloze exercises (e.g., on article placement), or converting grammar structures (e.g., converting active sentences to passive or questions into statements).

Example. If studying the third (or unreal past) conditional when reading the novella Rita Hayworth and the Shawshank Redemption (King, 1982), students could either find examples of the third conditional or create their own from facts. For example, they could use such sentences as the following as a base "The only two things I refuse to handle are guns and heavy drugs. I won't help anyone kill himself or anyone else" (p. 17). They could then 
convert it into a sentence such as the following: If someone had asked Red for a gun, he would have refused to help.

\section{Integrating Language Skills}

In addition to supporting the teaching of discrete skills, due to their length and varied content, novels are excellent vehicles to support the integration of skills. This includes the fifth skill, culture, as the following example suggests.

Example. The novel Fried Green Tomatoes (Flagg, 1987) takes place in the US South and offers many opportunities to teach units on Southern culture. The book opens with a menu for the new restaurant, the Whistle Stop Café. Students can begin by discussing the menu items for breakfast, lunch, and supper. Then they may draw a chart with the Whistle Stop's menu in the first column, some other meals they have heard are common in the US in the second, and meals from their own country in the third. A follow-up activity may include cooking a dinner together or going to a local restaurant and practicing the functions and notions as well as etiquette.

A facet of integrated language-learning particular to long fiction is that leitmotifs are developed throughout the text. For example, in The Color Purple (Walker, 1982), the themes of discrimination, feminism, and education are interwoven throughout the novel and presented in all their complexity. By focusing on subject matter over a longer period, students are given an excellent opportunity to contemplate issues in depth, explore them from various skill angles, and hone their analytical and critical thinking skills.

\section{Creating Assessments and Evaluations}

Tests used in regular ESOL classrooms can generally also be applied to novels. For example, one basic method of assessment when using novels as textbooks is to administer a short quiz with simple true/false questions after each reading assignment to check for overall comprehension. The anticipation of regular quizzes also encourages students to come to class prepared (Glenn, 2007), a factor essential for the success of in-class activities.

Due to the extensive nature of using novels, portfolios lend themselves well as assessments. Research papers can be written on issues in the novel; oral presentations, individual or group-based, can be given and recorded; and leading a discussion or creating a skit can be included as a performance assessment.

Instructors may follow established criteria and methodology (e.g., rubrics) for evaluation purposes. Like many activities, however, tests can also be produced by the students, which makes them fresh and new at every use. 


\section{Reflections}

Although novels do not include grammar charts, writing exercises, or tips on how to build vocabulary, they do offer plot, character development, the context of settings, suspense, conflict, and resolution, all of which contribute to the engagement of the reader. Such engagement can make the study of discrete or integrated skills a unique and memorable experience for ESOL students. The vocabulary, grammar, and style of a novel do not cater to specific proficiency levels, but they support the story being told, thus making every aspect of the reading authentic. Novels allow students to get caught up in the characters' lives and in the time and place of the setting. Thus they foster student-centered learning, where students construct their own meaning and relate it to their individual worlds and contexts. Counterbalancing the reduced predictability of language and grammar structures, authentic literature automatically recycles language (vocabulary, grammar, etc.) as it represents coherent characters and settings and a particular time. So it reinforces language acquisition naturally and continually.

One drawback of novels is that they do not present curricular items in a particular sequence as textbooks do. Nonetheless, a novel can still be used to support a set curriculum. If the curriculum calls for covering the past perfect, for example, students can write a letter or report about events in the novel using the past perfect. Or if lecture notetaking is to be taught, online lectures related to the themes of the novel (e.g., from YouTube.com) can serve for practice.

\section{Conclusion}

Provided that they are carefully chosen and used in conjunction with an appropriate timeline, novels can enrich classes for part or all of a term. If using a novel as a textbook seems too radical a leap from tradition in a given program, a pilot study using novels with one group of students or with an extra class of volunteer students might serve to examine the wonderful possibilities that extensive reading offers our language students. Similarly, if a teacher wishes to partner extensive reading with traditional reading, a course can be created to integrate textbook chapters with novels, thus gaining intensive and extensive skills as well as the enjoyment that comes from reading novels. Novels are exciting alternatives to textbooks in the ESOL class. Give them a try.

\section{The Authors}

Elisabeth Gareis is an associate professor in the Department of Communication Studies at Baruch College/City University of New York. She teaches intercultural and international communication and coordinates oral ESOL services at the college. Her research interests include intercultural friendship and integration of international students in the higher education context. 
Martine Allard is the Director of the English Language Institute (ELI) at Seneca College in Toronto. The ELI is a large intensive EAP program for international students and includes a TESL Canada and TESL Ontario certified Teacher Training program. The ELI also offers ESL programs in China.

Jackie Saindon is an ESL teacher at Gainesville State College and a part-time assistant professor at the University of Georgia. She has also taught community-level adult ESL. Her research interests include literacy education $\mathrm{K}-12$, postsecondary transitional programs, and the history and development of literacy in Mexico and the US.

\section{References}

Carrell, P.L., \& Carson, J.G. (1997). Extensive and intensive reading in EAP setting. English for Specific Purposes, 16(1), 47-60.

Cho, K.S., \& Krashen, S.D. (1994). Acquisition of vocabulary from the Sweet Valley Kids series: Adult ESL acquisition. Journal of Reading, 37(8), 662-667.

Day, R.R., \& Bramford, J. (1998). Extensive reading in the second language classroom. Cambridge, UK: Cambridge University Press.

Elley, W.B. (1991). Acquiring literacy in a second language: The effect of book-based programs. Language Learning, 41(3), 375-411.

Flagg, F. (1987). Fried green tomatoes. New York: Fawcett Columbine.

Gajdusek, L. (1988). Toward wider use of literature in ESL: Why and how. TESOL Quarterly, 22, 227-257.

Gareis, E. (1997). Literature and film adaptations: Dealing with hot topics in the ESL and literacy classroom. Journal of Adolescent and Adult Literacy, 41(3), 220-222.

Gareis, E., Allard, M.S., Gill, S., \& Saindon, J.J. (1997). A novel approach: Being there. Ann Arbor, MI: University of Michigan Press.

Gareis, E., Allard, M.S., Gill, S., \& Saindon, J.J. (1998). A novel approach: Fried green tomatoes. Ann Arbor, MI: University of Michigan Press.

Gareis, E., Allard, M.S., Gill, S., \& Saindon, J.J. (2000). A novel approach: Field of dreams. Ann Arbor, MI: University of Michigan Press.

Gareis, E., Allard, M.S., \& Saindon, J.J. (1998). A novel approach: Shawshank redemption. Ann Arbor, MI: University of Michigan Press.

Glenn, D. (2007, June 8). You will be tested on this. Chronicle of Higher Education, 53(40), A15-A17.

Grabe, W. (1991). Current developments in second language reading research. TESOL Quarterly, 25, 375-406.

Horst, M. (2005). Learning L2 vocabulary through extensive reading: A measurement study. Canadian Modern Language Review/La Revue Canadienne des Langues Vivantes, 61(3), 355-382.

Hunt, A., \& Beglar, D. (2005). A framework for developing EFL reading vocabulary. Reading in a Foreign Language, 17(1), 23-59.

Kesey, K. (1962). One flew over the cuckoo's nest. New York: Signet.

King, S. (1982). Rita Hayworth and the Shawshank redemption. In S. King Different seasons (pp. 15-106). New York: Signet.

Knight, S. (1994). Dictionary use while reading: The effects on comprehension and vocabulary acquisition for students of different verbal abilities. Modern Language Journal, 78(3), 285-299.

Kosinski, J. (1971). Being there. New York: Harcourt Brace Jovanovich.

Krashen, S. (1989). We acquire vocabulary and spelling by reading: Additional evidence for the input hypothesis. Modern Language Journal, 73(4), 440-464.

Kroeber, T. (1973). Ishi, last of his tribe. New York: Bantam.

Lazar, G. (1993). Literature and language teaching: A guide for teachers and trainers. New York: Cambridge University Press. 
MacGowan-Gilhooly, A. (1991). Fluency first: Reversing the traditional ESL sequence. Journal of Basic Writing, 10(1), 73-87.

Nation, I.S.P. (2001). Learning vocabulary in another language. Cambridge, UK: Cambridge University Press.

Orwell, G. (1951). Animal farm. Harmondsworth, UK: Penguin.

Pally, M. (1997). Screening English: Studying movies for reading, writing, and critical thinking. Edine, MN: Burgess.

Povey, J. (1979). The teaching of literature in advanced ESL classes. In M. Celce-Murcia \& L. McIntosh (Eds.), Teaching English as a second or foreign language (pp. 162-186). Rowley, MA: Newbury House.

Rodrigo, V. (1995). Does a reading programme work in a foreign language classroom. Paper presented at the Extensive Reading Colloquium, American Association of Applied Linguistics, Long Beach, CA.

Schneider, A. (2001). Can plot improve pedagogy? Novel textbooks give it a try. Chronicle of Higher Education, 47(35), A12-A14.

Seger, L. (1992). The art of adaptation: Turning fact and fiction into film. New York: Henry Holt and Company.

Vandrick, S. (1997). Reading and responding to novels in the university ESL classroom. Journal of the Imagination in Language Learning and Teaching, 4. Retrieved May 28, 2007, from: http:/ / www.njcu.edu/cill/journal-index.html

Walker, A. (1982). The color purple. New York: Pocket Books. 